\title{
Viewpoint - Ocean Plastic Pollution: a convenient but distracting truth?
}

Richard Stafford ${ }^{1 *}$ and Peter J.S. Jones ${ }^{2}$

${ }^{1}$ Department of Life and Environmental Sciences, Bournemouth University, Fern Barrow, Poole, BH12 5BB, UK, rstafford@bournemouth.ac.uk, Telephone: +44 (0) 1202966780 (*corresponding author)

${ }^{2}$ Department of Geography, University College London, Gower Street, London, WC1E 6BT, UK, P.J.Jones@ucl.ac.uk

https://doi.org/10.1016/j.marpol.2019.02.003

Published online 21 February 2019

Keywords: Plastic, Pollution, Climate Change, Fisheries, Biodiversity Loss, Marine Ecology

\section{Highlights:}

$>$ Plastic is not as great a threat to oceans as climate change or overfishing;

$>$ Corporations and governments focus on plastic to appear 'green';

$>$ There is a focus on technology and personal choice to reduce plastic;

$>$ Large-scale behavioural, economic and political changes are needed to tackle environmental issues.

\begin{abstract}
Ocean plastic is a contemporary focal point of concern for the marine environment. However, we argue there are bigger issues to address, including climate change and overfishing. Plastic has become a focus in the media and public domains partly through the draw of simple lifestyle changes, such as reusable water bottles, and partly through the potential to provide 'quick fix' technological solutions to plastic pollution, such as large scale marine clean-up operations and new 'biodegradable' plastic substitutes. As such, ocean plastic can provide a convenient truth that distracts us from the need for more radical changes to our behavioural, political and economic systems, addressing which will help address larger marine environmental issues, as well as the cause of plastic pollution, i.e. overconsumption.
\end{abstract}

This is the authors' version of the final accepted Marine Policy manuscript. Elsevier@ 2019. This manuscript version is made available under the CC-BY-NC-ND 4.0 license.

DOI:10.1016/j.marpol.2019.02.003

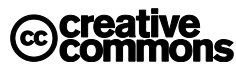

Stafford R and Jones PJS (2019) Viewpoint - Ocean plastic pollution: A convenient but distracting truth? Marine Policy 103, 187-191. https://doi.org/10.1016/j.marpol.2019.02.003. This manuscript version is made available under the CC-BY-NC-ND 4.0 license 


\section{Introduction}

Over recent years, and partly through several high-profile films and documentaries such as Blue Planet II, ocean plastic pollution has captured the public's attention [1]. Plastic pollution is visually impactful, and images of plastic filled shorelines or charismatic megafauna entangled or ingesting plastic have become common. Coastal marine litter is also readily noticeable by the public and can affect enjoyment of coastal areas [2]. Ingestion of and entanglement in plastic waste can cause the suffering and death of charismatic marine animals, such as seabirds, turtles and cetaceans, which become apparent when some wash up on beaches $[3,4]$. Public opinion has also altered industry behaviour and even government policies as a result of the high levels of public concern over plastic waste $[5,6]$, some recent actions and implementations being discussed further below.

However, recent reports from international organisations in the latter third of 2018 have indicated the severe level of threat to our planet and humanity from both climate change and biodiversity loss. The Intergovernmental Panel on Climate Change (IPCC) report demonstrated the urgency of action needed to keep warming within $1.5 \stackrel{\circ}{\circ}$, suggesting we have 12 years to make radical changes to our carbon emissions [7]. The Convention on Biological Diversity (CBD) has also indicated that biodiversity loss is another planetary emergency, and a recent interview with the executive secretary indicates that the upcoming CBD report will suggest we have only two years to reverse this current decline [8].

In this viewpoint, we argue that plastic pollution has been overemphasised by the media, governments and ultimately the public as the major threat to marine environments at the expense of climate change and biodiversity loss. We discuss why this can be a convenient truth, especially as some mechanisms to reduce plastic waste play into corporate greenwashing in a neoliberal economy rather than addressing the root cause of overconsumption of resources.

In this article, we first outline the importance of the core planetary boundaries of climate change and and biodiversity loss, before considering the scientific evidence on the ecological implications of ocean plastic. We explore individual, technological, political and economic solutions to environmental problems, concluding that major ecological and political reform is needed to successfully counter all of the major environmental issues affecting our marine environment.

\section{The importance of the core planetary boundaries of climate change and biodiversity loss}

Although the recent outputs from IPCC and the CBD $[7,8]$ have indicated a renewed urgency to climate change and biodiversity loss, the importance of these environmental threats are well established. When the concept of planetary boundaries (safe operating limits of the Earth for humanity) was introduced in 2009, boundaries for both climate change and biodiversity loss were already considered exceeded [9], with fishing playing a large role in reducing genetic, species and functional diversity of the ocean ecosystems $[10,11]$. These two planetary boundaries are presently, not only still exceeded, but considered the core planetary boundaries with the ability to shift the Earth system into a new state [12], hence needing urgent action to prevent major global changes.

Anthropogenic greenhouse gas emissions, largely from the burning of fossil fuels, are causing oceans to warm and acidify. Coral reefs bleach more frequently and have less recovery time with warming

Stafford R and Jones PJS (2019) Viewpoint - Ocean plastic pollution: A convenient but distracting truth? Marine Policy 103, 187-191. https://doi.org/10.1016/j.marpol.2019.02.003. This manuscript version is made available under the CC-BY-NC-ND 4.0 license 
temperatures [13], and predictions have indicated that coral reefs will be under severe threat unless temperature rises are urgently limited [13]. Climate change also affects many other marine systems, such as seagrass, with their ability for carbon sequestration, or kelp forests, which provide important nursery grounds for juvenile fish [14,15]. Climate change impacts are also associated with changing species and disease distributions, particularly from hotter lower latitude regions towards the poles, and such changes can also cause major ecological community change, and potentially also negatively affect biodiversity [15].

We are also rapidly depleting our seas of fish, especially of large predatory fish [10], which greatly influence community structure and potentially help regulate ocean carbon dynamics, helping mitigate anthropogenic carbon emissions [16]. The extent of this overfishing is becoming more apparent as we understand the true extent of historical under-reporting of catches [17]. Overfishing, along with associated habitat damage from bottom trawling, is drastically changing many ecological communities in our oceans [18], making them less resilient and potentially less able to supply food and other ecosystem services to the most vulnerable communities who rely on fish as a source of protein [19].

\section{Is ocean plastic at a planetary boundary level?}

Whilst it is clear that ocean plastic pollution is a problem which needs to be addressed, there is considerably less evidence of its effects at a planetary, ecological or toxicological level. While it is well documented that ingestion of large plastic items or entanglement in plastic debris such as nets causes harm to many marine animals and seabirds, the population effects of these deaths are largely unknown $[20,21]$, though there is for evidence of reduced juvenile survival in some species [see 22]. Plastic is known to break down into microplastics, the ecosystem and physiological and toxicological effects of which are largely unknown, but generally considered a lower risk than ingestion of larger plastic items $[20,23]$. A recent assessment of the threat caused by ocean plastic has demonstrated that there is evidence, but not full consensus, that plastic pollution should be considered as nearly reaching planetary boundary thresholds (safe operating limits for humanity) [24]. Therefore, efforts to tackle plastic pollution are important, but not as pressing as for the long-exceeded core planetary boundaries of climate change and biodiversity loss.

\section{Individual actions to environmental problems}

The media attention given to plastic pollution has generated considerable interest in individual action to reduce personal use of, especially, single use plastics [25]. Carrying reusable coffee cups and water bottles and refusing plastic straws are perhaps the best examples of this. It could be argued that individuals, corporations and governments recognising and reducing plastic consumption will lead to other lifestyle and policy changes that will progress to addressing climate change and overfishing, i.e. the 'gateway' view, or it could argued that optimism engendered by reducing plastic consumption could lead to apathy and continued flights, consumerist over-consumption, etc., i.e. the 'complacency' view, at a crucial window in time for the more radical actions that are urgently needed to mitigate climate change $[26,27]$. Whilst there may be some capacity for the former, we fear that the latter could be more likely.

Stafford R and Jones PJS (2019) Viewpoint - Ocean plastic pollution: A convenient but distracting truth? Marine Policy 103, 187-191. https://doi.org/10.1016/j.marpol.2019.02.003. This manuscript version is made available under the CC-BY-NC-ND 4.0 license 
At an individual level, we can understand some, perhaps more shallow aspects of plastic pollution awareness as a projection of personal image. This is especially true for the younger generation with their personal image being presented on social media [28]. Plastic pollution is not only a visible reality, but also individual solutions to plastic pollution such as the use of reusable bottles and coffee cups are themselves visible, and shareable on social media, creating the perfect ground for 'environmental branding' of individuals and even corporations. Even community activities such as beach cleans can correlate positive environmental behaviour with photograph opportunities. Much research is emerging that demonstrates that self-curation of personal image is important on social media [28-30], and sharing photographs and videos of using environmental products is likely to enhance this self-image. Climate change and biodiversity loss do not possess the same branding incentives; 'not flying', for example, is not something easily shared or 'instagram-able', and hence some motivations for individualistic actions against plastic pollution are unlikely to be transferable to other environmental issues.

There is also evidence of a single-issue focus in environmental issues. In a study in 2008, previous interest in biodiversity loss in the environmentally aware public had been largely lost and replaced with a focus (amongst those engaged in environmental issues) on climate change [31]. Given public apathy for long-term environmental concerns such as climate change [32, 33], it is evident that plastics now occupy this environmental focus, likely at the expense of other concerns. Plastic pollution also occupies individuals' concerns for the marine environment, where other environmental issues such as climate change and biodiversity loss have always been less well recognised in marine systems than in terrestrial systems [34].

There is, however, evidence that individual actions have created a market demand for fewer plastic products. For example, many coffee shops now offer discounts to customers using their own cups or extra charges for customers who do not bring their own cups. This could be seen as a success of classic neoliberal policy, in that markets will adjust to meet changing customer demand. However, there is no evidence that the uptake of re-usable coffee cups has reduced the number of single-use coffee cups, whilst in some cases, changes to alternatives are not as environmentally sound as customers may believe. A recent petition to force high street retailers to move to cornstarch coffee cups was high profile on social media, but few people questioned the complexities of changes in land use needed to grow the cornstarch and the implications of land lost to food production [35]. Furthermore, the 'lifestyle' changes common in shallow level activism against plastic pollution (from carrying reusable cups to going plastic free for a month) are relatively simple. The individual level choices to prevent climate change are more challenging. For example, permanently changing diet away from meat and many kinds of fish is needed [36] as is reducing consumerist consumption patterns, car reliance and aeroplane flights, or more controversially, reducing our number of children [37].

As such, a focus on individual level action, at least at the level of the 'how to make a difference' checklists common on social media, is unlikely to successfully address the complex environmental issues we face today [38], and may even be a distraction from the need to make structural changes to our societal, political and economic systems [39, 40].

Stafford R and Jones PJS (2019) Viewpoint - Ocean plastic pollution: A convenient but distracting truth? Marine Policy 103, 187-191. https://doi.org/10.1016/j.marpol.2019.02.003. This manuscript version is made available under the CC-BY-NC-ND 4.0 license 


\section{Technological solutions to environmental problems}

Technological solutions to environmental problems can fall into two categories. Firstly, the classic neoliberalist consumer choice argument often produces alternative products to maintain the status quo of the economy. For example, cornstarch coffee cups, as indicated above, are a solution to avoid plastic, but allow coffee shops to continue as before, likely with increased costs passed onto customers. Such solutions can also have different environmental consequences to the initial problems they address [35]. At a larger scale, technology can offer solutions to environmental issues, seemingly without changes needing to be made to our consumerist lifestyles. For example, the recently launched Ocean Cleanup project proposes to remove $50 \%$ of plastic in ocean gyres in a five-year period, essentially by sieving the surface waters [41]. However, the project is far from perfect, as it is well-documented that much of the plastic in the ocean is absent from surface waters [42,43] and that the device will be unable to remove microplastics from the water [44]. Critics suggest that the project deflects from the root cause of many ocean plastics, our over reliance on conveniently packed goods [41], as well as discarded or lost fishing equipment, often from poorly managed fishing practices [45].

Technological solutions also exist for addressing climate change, and ideas such as switching to energy efficient light-bulbs and other household appliances have long been suggested as typical climate change prevention responses common in many key educational texts [37]. However, recent work has indicated that switching to a more efficient car and buying green energy are some of the only technological solutions with major carbon impacts, and switching light bulbs to energy efficient bulbs has only a low impact on carbon output of a typical home [37].

However, technological solutions can also form part of more radical changes, such as forming part of the circular economy, where there is a stronger emphasis on reuse and recycling [46]. For effective plastic recycling, technological input is vital, as plastic currently degrades each time it is recycled. New approaches can begin to address these concerns and prevent plastic waste as well as fossil fuel extraction to create new products [47]. For climate change and biodiversity loss, technical solutions allow further reuse and recycling of products, reducing the energy requirements of production [48] and limiting the extraction of natural resources which may lead to habitat degradation and biodiversity loss [46]. As such, technological solutions can play a role, but achieve the most when combined with a new political and economic outlook to the environment.

\section{Political and economic solutions to environmental problems}

Addressing global level environmental concerns requires major changes in human behaviour, as well as major changes to industry practices, many of which are likely to be unpopular with all involved. Most people understandably feel overwhelmed and disempowered by the severity and urgency of, in particular, climate change and the threat it represents to the future of humanity and our oceans, whilst corporations and governments (and some people) may fear that addressing climate change will call our collective focus on consumption, materialism and economic growth into question [40]. At an international level, restructuring our economy to reduce inequity, promoting open source ideas around product reuse (such as the circular economy ideas discussed above), and finding alternative metrics to well-being beyond our myopic focus on economic growth are all key to achieving global sustainability and related environmental goals [26]. While some aspects of these required changes are being

Stafford R and Jones PJS (2019) Viewpoint - Ocean plastic pollution: A convenient but distracting truth? Marine Policy 103, 187-191. https://doi.org/10.1016/j.marpol.2019.02.003. This manuscript version is made available under the CC-BY-NC-ND 4.0 license 
addressed (i.e. technological solutions within the circular economy as discussed above), many others are not.

Political solutions can also be more effective in reduction of environmental harm than individual choices, even if individual choices are made on mass. For example, while flying is one of the major individual level changes which can be made to reduce carbon emissions [37], globally it equates to $<2 \%$ of carbon emissions, due to the low number of people flying at a global level. It is therefore better for a long-haul flyer, to restrict flying than to restrict meat consumption, yet globally, reduction of meat consumption would have a far greater reduction in carbon emissions [36]. While reduction in flying is clearly important, at a political level, it would be more effective to tax meat consumption or production the reduce carbon (although the optimal solution may vary by country).

In practice, environmental policy which affects the marine environment is now mostly encapsulated in Sustainable Development Goal 14, "Conserve and sustainably use the oceans, seas and marine resources" [49]. This goal incorporates much policy regarding fisheries, marine protected areas, pollution (including plastics) and climate change and acidification effects. While SDG14 has developed recently, it encapsulates many ideas central to marine policy developed over several decades [50]. However, internationally, we are not on target with carbon emission goals [51]. Marine protected areas are frequently poorly governed and ineffective $[52,53]$ and we are currently below a $10 \%$ target of marine protected areas, despite recent scientific research calling for $30 \%$ protection [54]. Not only are $33 \%$ of fisheries classed as overfished [55], but many high seas fisheries would not be economically profitable unless subsidised by governments [56]. As such, there is a clear shortfall in current political and economic thinking surrounding the main marine environmental issues.

In terms of plastic pollution, however, there have been several recent flagship policy announcements. For example, plastic bag bans or charges by supermarkets have been shown to lead to a demonstrable reduction in plastic bag uptake in many countries and some evidence of environmental benefits have been found as a result [5]. The European Union has recently proposed a ban on single use plastics, some to be phased out by 2022 , with $95 \%$ of bottles being recycled by 2025 , and a $25 \%$ reduction in plastics with no alternative by 2025 [57]. The UK has committed to "achieving zero avoidable plastic waste by the end of 2042" in its recent 25 year plan [6], although it has made moves towards eliminating some kinds of single use plastic sooner.

While it is possible to argue that these policies could be extended to more types of plastic than just 'avoidable plastic waste', or could be introduced more quickly, it is clear that increased public awareness may have contributed to rapid formation of government policy in terms of plastic pollution [58].

\section{Is plastic a convenient, but distracting truth?}

At present the Earth faces a number of major anthropogenic environmental threats. Largely these have a common cause, overconsumption of natural resources by a growing population. As discussed, to fully address these threats, including the root cause of plastic pollution, large-scale political and economic change is needed $[25,39,59,60]$. However, plastic pollution has captured the attention of many people and the levels of concern within the population have created (small) changes in industry practices, and government policy which work within existing political and economic frameworks, cause minimum

Stafford R and Jones PJS (2019) Viewpoint - Ocean plastic pollution: A convenient but distracting truth? Marine Policy 103, 187-191. https://doi.org/10.1016/j.marpol.2019.02.003. This manuscript version is made available under the CC-BY-NC-ND 4.0 license 
disruption to industry, but ultimately fail to address the root cause of environmental issues. If, as discussed above, the momentum of the anti-plastic campaigns cannot be mobilised to support more than one environmental cause, and if governments can be seen to be fulfilling their environmental obligations by introducing policies such as slowly phasing out 'avoidable' plastic packaging, we argue that ocean plastic pollution has created a convenient truth to distract environmental policy from more serious and urgent threats.

\section{The way forward for addressing global scale environmental issues}

To address the current environmental threats we face, it is clear we need collective action at an international level [61]. Many individual actions, such as using reusable coffee cups, buying sustainably caught fish or replacing light bulbs with energy efficient alternatives, may have some effect within the current dominant neoliberal political system. For example, they are likely to have the greatest effect, not in directly reducing plastic pollution, preventing overfishing or reducing carbon emissions, but in altering the behaviour of retailers offering these products, or in shaping small changes to government policy.

Individuals need to target political systems to create real environmental change. At its most basic form, this should include voting, but as history demonstrates, collective action relies on education (often informal education and discussion) and challenging the status quo of debate [38]. Developing effective environmental governance strategies at local, national and global levels is also likely to provide integrated solutions to environmental problems [61,62], but also strengthen the case for political reform [63].

As scientists we have an important role in clearly describing the scale of environmental threats and what can be done to prevent them. This role would include not overselling less important environmental issues to publish in high-impact journals. Nor would it involve avoiding addressing important issues such as climate change or jumping on new bandwagons when funding sources shift their priority focus. Policy makers and NGOs need to consider solutions to problems beyond the confines of market economics, especially when adherence to the laws of supply and demand do not afford optimal solutions. Finally, politicians need to think beyond re-election in making decisions that may be for the benefit of the country or planet. These decisions need to be discussed and implemented even if initially unpopular with the electorate, and they need to focus on environmental benefits of action, and environmental consequences of inaction, rather than solely economic benefits as is currently the norm.

\section{Conclusions}

It is not our intention in this article to question the importance of reducing plastic pollution, but to highlight how it is a relatively convenient environmental issue on which we are focusing, at the expense of neglecting other more pressing concerns. While small steps have been taken or are planned to help reduce plastic waste, this should not prevent the large-scale systemic changes needed internationally to tackle all environmental concerns, including longer-term more effective solutions to the plastic problem, but extending to more radical large-scale initiatives to reduce consumption, decarbonise economies and move beyond materialism as the basis for our well-being [26]. The focus needs to be on making the way we live more sustainable by questioning our over-consumptive consumerist lifestyles, rather than a

Stafford R and Jones PJS (2019) Viewpoint - Ocean plastic pollution: A convenient but distracting truth? Marine Policy 103, 187-191. https://doi.org/10.1016/j.marpol.2019.02.003. This manuscript version is made available under the CC-BY-NC-ND 4.0 license 
narrower focus on sustainable consumer choices, i.e. reform the way we live rather than tweak the choices we make.

\section{References:}

[1] Thompson, R. (2017). Environment: A journey on plastic seas. Nature, 547, 278. https://doi.org/10.1038/547278a

[2] Pahl, S., Wyles, K. J., \& Thompson, R. C. (2017). Channelling passion for the ocean towards plastic pollution. Nature Human Behaviour, 1, 697-699. https://doi.org/10.1038/s41562-017-0204-4

[3] Nelms, S. E., Duncan, E. M., Broderick, A. C., Galloway, T. S., Godfrey, M. H., Hamann, M., ... \& Godley, B. J. (2015). Plastic and marine turtles: a review and call for research. ICES Journal of Marine Science, 73(2), 165-181. https://doi.org/10.1093/icesjms/fsv165

[4] Derraik, J. G. (2002). The pollution of the marine environment by plastic debris: a review. Marine Pollution Bulletin, 44, 842-852. https://doi.org/10.1016/S0025-326XXanthos(02)00220-5

[5]. Xanthos, D., \& Walker, T. R. (2017). International policies to reduce plastic marine pollution from single-use plastics (plastic bags and microbeads): a review. Marine pollution bulletin, 118, 17-26. https://doi.org/10.1016/j.marpolbul.2017.02.048

[6]. DEFRA 2018. A Green Future: Our 25 Year Plan to Improve the Environment. Department for Environment, Fisheries and Rural Affairs: London. https://www.gov.uk/government/publications/25year-environment-plan

[7]. IPCC 2018. Special Report on Global Warming of $1.5^{\circ} \mathrm{C}$ (SR15). Intergovernmental Panel on Climate Change: Geneva. http://www.ipcc.ch/pdf/special-reports/sr15/sr15_draft.pdf

[8] Watts J. 2018. Stop biodiversity loss or we could face our own extinction, warns UN. The Guardian. https://www.theguardian.com/environment/2018/nov/03/stop-biodiversity-loss-or-we-could-face-ourown-extinction-warns-un. Accessed 8th November 2018.

[9]. Rockström, J., Steffen, W., Noone, K., Persson, Å., Chapin III, F. S., Lambin, E., ... \& Nykvist, B. (2009). Planetary boundaries: exploring the safe operating space for humanity. Ecology and Society, 14, 32. https://www.ecologyandsociety.org/vol14/iss2/art32/

[10]. Worm, B., Sandow, M., Oschlies, A., Lotze, H. K., \& Myers, R. A. (2005). Global patterns of predator diversity in the open oceans. Science, 309, 1365-1369. https://doi.org/10.1126/science.1113399

[11]. Olsen, E. M., Heino, M., Lilly, G. R., Morgan, M. J., Brattey, J., Ernande, B., \& Dieckmann, U. (2004). Maturation trends indicative of rapid evolution preceded the collapse of northern cod. Nature, 428, 932935. https://doi.org/10.1038/nature02430

[12]. Steffen, W., Richardson, K., Rockström, J., Cornell, S. E., Fetzer, I., Bennett, E. M., ... \& Folke, C. (2015). Planetary boundaries: Guiding human development on a changing planet. Science, 347(6223), 1259855. https://doi.org/10.1126/science.1259855

[13]. Hughes, T. P., Anderson, K. D., Connolly, S. R., Heron, S. F., Kerry, J. T., Lough, J. M., ... \& Claar, D. C. (2018). Spatial and temporal patterns of mass bleaching of corals in the

Anthropocene. Science, 359(6371), 80-83. https://doi.org/10.1126/science.aan8048

[14]. Orth, R. J., Carruthers, T. J., Dennison, W. C., Duarte, C. M., Fourqurean, J. W., Heck, K. L., ... \& Short, F. T. (2006). A global crisis for seagrass ecosystems. Bioscience, 56, 987-996. https://doi.org/10.1641/0006-3568(2006)56[987:AGCFSE]2.0.CO;2

[15]. Hoegh-Guldberg, O., \& Bruno, J. F. (2010). The impact of climate change on the world's marine ecosystems. Science, 328(5985), 1523-1528. https://doi.org/10.1126/science.1189930

Stafford R and Jones PJS (2019) Viewpoint - Ocean plastic pollution: A convenient but distracting truth? Marine Policy 103, 187-191. https://doi.org/10.1016/j.marpol.2019.02.003. This manuscript version is made available under the CC-BY-NC-ND 4.0 license 
[16]. Spiers, E. K., Stafford, R., Ramirez, M., Izurieta, D. F. V., Cornejo, M., \& Chavarria, J. (2016). Potential role of predators on carbon dynamics of marine ecosystems as assessed by a Bayesian belief network. Ecological informatics, 36, 77-83. https://doi.org/10.1016/j.ecoinf.2016.10.003

[17]. Pauly, D., \& Zeller, D. (2016). Catch reconstructions reveal that global marine fisheries catches are higher than reported and declining. Nature communications, 7, 10244.

https://doi.org/10.1038/ncomms10244

[18]. Dayton, P. K., Thrush, S., \& Coleman, F. C. (2002). Ecological Effects of Fishing. Pew Oceans Commission: Arlington. https://cresli.org/ creslior/cresli/pdf\%20documents/POC_EcoEffcts_Rep2.pdf

[19]. Golden, C., Allison, E. H., Cheung, W. W., Dey, M. M., Halpern, B. S., McCauley, D. J., ... \& Myers, S. S. (2016). Fall in fish catch threatens human health. Nature, 534(7607), 317-320. https://doi.org/10.1038/534317a

[20]. Wilcox, C., Mallos, N. J., Leonard, G. H., Rodriguez, A., \& Hardesty, B. D. (2016). Using expert elicitation to estimate the impacts of plastic pollution on marine wildlife. Marine Policy, 65, 107-114. https://doi.org/10.1016/j.marpol.2015.10.014

[21]. Rochman, C. M., Browne, M. A., Underwood, A. J., van Franeker, J. A., Thompson, R. C., and Amaral-Zettler, L. A. (2016). The ecological impacts of marine debris: unraveling the demonstrated evidence from what is perceived. Ecology 97, 302-312. https://doi: 10.1890/14-2070.1

[22]. Lavers, J. L., Bond, A. L., and Hutton, I. (2014). Plastic ingestion by flesh-footed shearwaters (Puffinus carneipes): implications for fledgling body condition and the accumulation of plastic-derived chemicals. Environmental Pollution 187, 124-129. https://doi: 10.1016/j.envpol.2013.12.020

[23]. Burton, G. A. 2017. Stressor exposures determine risk: So, why do fellow scientists continue to focus on superficial microplastics risk? Environmental Science and Technology. 51, 13515-13516, https://doi.org/10.1021/acs.est.7b05463

[24].Villarrubia-Gómez, P., Cornell, S. E., \& Fabres, J. (2018). Marine plastic pollution as a planetary boundary threat - the drifting piece in the sustainability puzzle. Marine Policy. 96, 213-220.

https://doi.org/10.1016/j.marpol.2017.11.035

[25]. Ten Brink, P., Schweitzer, J. P., Watkins, E., Janssens, C., De Smet, M., Leslie, H., \& Galgani, F. 2018. Circular economy measures to keep plastics and their value in the economy, avoid waste and reduce marine litter. Economics Discussion Papers, 2018-3

http://www.economics-ejournal.org/economics/discussionpapers/2018-3

[26]. Raworth, K. (2017). Why it's time for Doughnut Economics. IPPR Progressive Review, 24(3), 216 -

222. https://doi.org/10.1111/newe.12058

[27]. Steffen, W., Rockström, J., Richardson, K., Lenton, T. M., Folke, C., Liverman, D., ... \& Donges, J. F. (2018). Trajectories of the Earth System in the Anthropocene. Proceedings of the National Academy of Sciences of the United States of America. 115, 8252-8259. https://doi.org/10.1073/pnas.1810141115 [28]. Marom, D., 2017. Curating the self on social media and perceptions of authenticity: an exploratory study (Doctoral dissertation). University of Texas: Austin.

https://repositories.lib.utexas.edu/handle/2152/60382

[29]. Walther, J. B. (2007). Selective self-presentation in computer-mediated communication: Hyperpersonal dimensions of technology, language, and cognition. Computers in Human Behavior, 23, 2538-2557. https://doi.org/10.1016/j.chb.2006.05.002

[30]. Wright, E.J., White, K.M. and Obst, P.L. 2018. Facebook False Self-Presentation Behaviors and Negative Mental Health. Cyberpsychology, Behavior, and Social Networking, 21, 40-49. https://doi.org/10.1089/cyber.2016.0647

Stafford R and Jones PJS (2019) Viewpoint - Ocean plastic pollution: A convenient but distracting truth? Marine Policy 103, 187-191. https://doi.org/10.1016/j.marpol.2019.02.003. This manuscript version is made available under the CC-BY-NC-ND 4.0 license 
[31]. Novacek, M.J., 2008. Engaging the public in biodiversity issues. Proceedings of the National Academy of Sciences. 105:11571-11578. https://doi.org/10.1073/pnas

[32]. Norgaard, K.M., 2011. Living in denial: Climate change, emotions, and everyday life. MIT Press: Cambridge MA

[33]. Antadze, N., 2018. The politics of apathy: Trumping the ethical imperative of climate change. Ethics, Policy \& Environment, 21, 45-47. https://doi.org/10.1080/21550085.2018.1448034

[34]. Jefferson, R.L., Bailey, I., Richards, J.P. and Attrill, M.J., 2014. Public perceptions of the UK marine environment. Marine Policy, 43, 327-337. https://doi.org/10.1016/j.marpol.2013.07.004

[35]. Monbiot G. (2018). We won't save the Earth with a better kind of disposable coffee cup. The Guardian. https://www.theguardian.com/commentisfree/2018/sep/06/save-earth-disposable-coffeecup-green. Accessed 13th Sept. 2018

[36]. Poore, J., \& Nemecek, T. (2018). Reducing food's environmental impacts through producers and consumers. Science, 360, 987-992. https://doi.org/10.1126/science.aaq0216

[37]. Wynes, S., \& Nicholas, K. A. (2017). The climate mitigation gap: education and government recommendations miss the most effective individual actions. Environmental Research Letters, 12, 074024. https://doi.org/10.1088/1748-9326/aa7541

[38]. Adams M. 2018. Individual action won't achieve $1.5^{\circ} \mathrm{C}$ warming - social change is needed, as history shows. The Conversation. https://theconversation.com/individual-action-wont-achieve-1-5warming-social-change-is-needed-as-history-shows-104643 Accessed 19th November 2018.

[39]. Lukacs M. 2017. Neoliberalism has conned us into fighting climate change as individuals. The Guardian. https://www.theguardian.com/environment/true-north/2017/jul/17/neoliberalism-hasconned-us-into-fighting-climate-change-as-individuals. Accessed $1^{\text {st }}$ December 2018.

[40]. Bellamy Foster J. 2017. The Earth-system crisis and ecological civilization: a Marxian view. International Critical Thought. 7, 439-458. https://doi.org/10.1080/21598282.2017.1357483

[41]. Stokstad, E. (2017) Sea trash traps face doubts. Science. 356: 671.

https://doi.org/10.1126/science.356.6339.671

[42]. Eriksen, M., Lebreton, L.C., Carson, H.S., Thiel, M., Moore, C.J., Borerro, J.C., Galgani, F., Ryan, P.G. and Reisser, J. (2014). Plastic pollution in the world's oceans: more than 5 trillion plastic pieces weighing over 250,000 tons afloat at sea. PLoS one, 9 e111913. https://doi.org/10.1371/journal.pone.0111913 [43]. Woodall, L.C., Sanchez-Vidal, A., Canals, M., Paterson, G.L., Coppock, R., Sleight, V., Calafat, A., Rogers, A.D., Narayanaswamy, B.E. and Thompson, R.C. (2014). The deep sea is a major sink for microplastic debris. Royal Society open science, 1, 140317. https://doi.org/10.1098/rsos.140317 [44]. Slat B. (2014). How the oceans can clean themselves: a feasibility study. The Ocean Cleanup: Delft.https://www.theoceancleanup.com/fileadmin/mediaarchive/Documents/TOC_Feasibility_study_lowres_V2_0.pdf [45]. Li, W. C., Tse, H. F., \& Fok, L. (2016). Plastic waste in the marine environment: A review of sources, occurrence and effects. Science of the Total Environment, 566, 333-349.

https://doi.org/10.1016/j.scitotenv.2016.05.084

[46]. Ellen MacArthur Foundation. 2012. Towards the Circular Economy. Ellen MacArthur Foundation: Cowes. https://www.ellenmacarthurfoundation.org/assets/downloads/publications/Ellen-MacArthurFoundation-Towards-the-Circular-Economy-vol.1.pdf [47]. Ellen MacArthur Foundation. 2017. The new plastics economy: rethinking the future of plastics and catalysing action. Ellen MacArthur Foundation: Cowes.

Stafford R and Jones PJS (2019) Viewpoint - Ocean plastic pollution: A convenient but distracting truth? Marine Policy 103, 187-191. https://doi.org/10.1016/j.marpol.2019.02.003. This manuscript version is made available under the CC-BY-NC-ND 4.0 license 
https://www.ellenmacarthurfoundation.org/publications/the-new-plastics-economy-rethinking-thefuture-of-plastics-catalysing-action

[48]. Pantsar M \& Laita S. 2018. The circular economy - a powerful force for climate mitigation. Material Economics Sverige AB: Stockholm. https://www.sitra.fi/en/publications/circular-economy-powerfulforce-climate-mitigation

[49]. United Nations. 2016. United Nations Sustainable Development Goals: Goal 14 Conserve and sustainably use the oceans, seas and marine resources. United Nations. New York.

https://www.un.org/sustainabledevelopment/oceans/

[50]. Zacharias, M. 2014. Marine Policy: an Introduction to Governance and International Law of the Oceans. Routledge: London.

[51]. Rogelj, J., Den Elzen, M., Höhne, N., Fransen, T., Fekete, H., Winkler, H., ... \& Meinshausen, M.

(2016). Paris Agreement climate proposals need a boost to keep warming well below 2

C. Nature, 534(7609), 631. https://doi.org/10.1038/nature18307

[52] Jones, P. J. S., W. Qiu, and E. M. De Santo. 2011. Governing marine protected areas: getting the balance right. Technical report. United Nations Environment Programme, Nairobi .

[53] Edgar, G. J., Stuart-Smith, R. D., Willis, T. J., Kininmonth, S., Baker, S. C., Banks, S., ... \& Buxton, C. D. (2014). Global conservation outcomes depend on marine protected areas with five key features. Nature, 506(7487), 216-220. https://doi.org/10.1038/nature13022

[54] O'Leary, B. C., Winther-Janson, M., Bainbridge, J. M., Aitken, J., Hawkins, J. P., \& Roberts, C. M. (2016). Effective coverage targets for ocean protection. Conservation Letters, 9, 398-404.

https://doi.org/10.1111/conl.12247

[55]. FAO. 2018. The State of World Fisheries and Aquaculture 2018 - Meeting the sustainable

development goals. Food and Agriculture Organisation: Rome.

http://www.fao.org/3/19540EN/i9540en.pdf

[56]. Sala, E., Mayorga, J., Costello, C., Kroodsma, D., Palomares, M. L., Pauly, D., ... \& Zeller, D. (2018).

The economics of fishing the high seas. Science advances, 4(6), eaat2504.

https://doi.org/10.1126/sciadv.aat2504

[57]. Bourguignon D. 2018. Single-use plastics and fishing gear. EU legislation in Progress. European Union: Brussels.

http://www.europarl.europa.eu/RegData/etudes/BRIE/2018/625115/EPRS_BRI(2018)625115_EN.pdf [58]. Chow CF., So WM.W., Cheung TY., Yeung SK.D. (2017) Plastic Waste Problem and Education for Plastic Waste Management. In: Kong S., Wong T., Yang M., Chow C., Tse K. (eds) Emerging Practices in Scholarship of Learning and Teaching in a Digital Era. Springer: Singapore. https://doi.org/10.1007/978981-10-3344-5_8

[59]. Gore A., 2006. An Inconvenient Truth: the planetary emergency of global warming and what we can do about it. Bloomsbury: New York. https://www.bloomsbury.com/uk/an-inconvenient-truth9780747589068/

[60]. Carter, N. (2018). The politics of the environment: Ideas, activism, policy. Third Edition. Cambridge University Press: Cambridge.

[61]. Vince, J., Stoett, P. (2018). From problem to crisis to interdisciplinary solutions: Plastic marine debris. Marine Policy. 96: 200-203. https://doi.org/10.1016/j.marpol.2018.05.006

[62]. Vince, J., Hardesty, B. D. (2017). Plastic pollution challenges in marine and coastal environments: from local to global governance. Restoration Ecology, 25, 123-128. https://doi.org/10.1111/rec.12388 [63]. Monbiot, G. 2017. Out of the Wreckage: a New Politics for an Age of Crisis. Verso: London.

Stafford R and Jones PJS (2019) Viewpoint - Ocean plastic pollution: A convenient but distracting truth? Marine Policy 103, 187-191. https://doi.org/10.1016/j.marpol.2019.02.003. This manuscript version is made available under the CC-BY-NC-ND 4.0 license 